\title{
岩石の一軸圧縮強度実験結果のばらつきに関する研究
}

\section{STRENGTH DISTRIBUTION OF ROCK SPECIMENS AND EXPERIMENTAL TECHNIQUES}

\author{
佐野 修*.工藤洋三**.古川浩平***. 中川浩二**** \\ By Osamu SANO, Yozo KUDO, Kohei FURUKAWA and Kö̈ NAKAGAWA
}

\begin{abstract}
The concept that the compressive strength of rocks usually falls within the range of two or three times the strength of its minimum value seems to be accepted in engineering fields in Japan. The authors suggest that such a wide distribution of the strength was from the experimental conditions. Carefully arranged experiments (experiments : No. 1) and normal experiments (No. 2) were carried out. Although the same granite specimens were used, the scattering of the data in No. 1 was very small but the data in No. 2 was scattered widely. The applied bending moment was calculated from the strain deviation of four axial strains at the periphery of each cylindrical specimen. The observed strength decreased with increasing bending moment. The strike of the fault was nearly parallel to the rift plane for the carefully arranged experiments. However, in experiments No. 2, the strike varied widely, showing that the intrinsic nature of the rock can not be easily discovered because of the disturbances of the experimental techniques.
\end{abstract}

Keywords : compressive strength, strength distribution, granite, anisotropy

\section{1. 緒 論}

岩石の一軸圧縮強度は岩石の代表的な物理量として, 岩石物性の研究の対象のみならず岩盤構造物の設計・施 工のための資料として用いられてきている. そのため数 えきれないほど多くの研究が岩石の一軸圧縮実験につい てなされてきており,その内容は多方面にわたっている. これらの研究の中には岩石供試体の一軸圧縮強度のばら

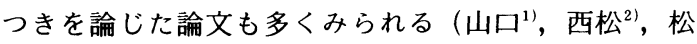

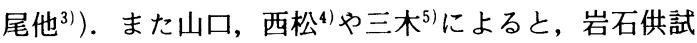
体の一軸圧縮強度は, 読取り誤差や計測器のドリフトな どによる計測誤差と比較してはるかに大きなばらつきを 有するものと考えられているようである.

それらの研究の多くでは, 岩石は本来その組織・構造 上クラック等の内部欠陥を多数含むため材料固有の強度 にばらつきが生じるものと考えられており, Griffith の 破壊理論との関連で強度のばらつきが説明されている.

* 正会員 工博 山口大学助手 工学部資源工学科 （ T755 山口県宇部市常盤台 2557）

** 正会員 工修 徳山工業高等専門学校助教授 土木工学 科（ 7745 山口県徳山市大字久米字高城 3538）

*** 正会員 工博 山口大学助教授 工学部建設工学科 （テ755 山口県宇部市常盤台 2557）

**** 正会員 工博 山口大学教授 工学部建設工学科 (同上)
さらにそこでは強度の分布特性をもとに，一軸圧縮強度 の信頼できる実験結果を得るためにどの程度の供試体数 が必要かが論じられている. 岩石の強度の大きなばらつ きは基本的には最弱リンクの概念により説明されてい るが4), 近年の岩石力学では大きな欠陥のない岩石の 破壊は多数の微少破壊の集積によるものと考えられてお $り^{6)}$, 最弱リンク説から得られる概念は再検討する必要 があると思われる.

一方いくつかの研究では岩石物性が非常に少ない実験 供試体数のもとに論じられており(たとえば Mogi ${ }^{7), 8)}$ や Brace et al. $\left.{ }^{9)}\right)$, 時には 1 つの実験条件下での供試体 数が 1 個という例もみられる (Sano et al. ${ }^{10), 11)}$ ). これ らの研究では岩石の強度のばらつきは山口, 西松4およ び三木 ${ }^{5)}$ に述べられているほよ゙大きくはないと考えられ ているようである.

岩石供試体の一軸圧縮実験結果に大きなばらつきを生 じる原因は, (1)岩石材料固有のばらつき, (2)岩石供試体 作製上のばらつき, (3)試験条件のばらつきの 3 つに大き く分けることができよう.そして実験結果のばらつきは これら 3 つ原因によるばらつきの複合的な効果として 生じると考えられる. いまこれらの 3 つのばらつきはそ れぞれ何らかの分布をもっているとしても, それぞれの ばらつきが小さくなれば実験結果のばらつきは小さくな 
るであろう.すなわち上記の(2)，(3)の 2 つのばらつきを 極力小さくした実験を行うことによってのみ岩石材料固 有のばらつきを明らかにすることができる.

本研究では大きな欠陥のない岩石を用い，上述の考え 方をもとに岩石供試体作製上のばらつきと武験条件のば らつきを極力小さくした念入りな実験を行い, 岩石固有 のばらつきがごの程度であるかを明らかにすることを意 図したものである.さらに(1)および(2)の岩石材料と供試 体作製法とを先の実験と同一の条件にしたうえで, 通常 行われていると考えられる手法で実験を行い, (3)の試験 条件のばらつきが岩石の一軸圧縮実験結果のばらつきに 与える影響を検討した．ただし本研究では実験と試験と いう語を便宜上次のように使い分けることにする．すな わち実験とは試料の採取から供試体の整形, 載荷にわた る全過程を指し,試験とは供試体を載荷する過程を指す。

\section{2. 岩石の一軸圧縮実験結果にばらつきを与え る要因}

岩石の一軸圧縮実験結果にばらつきを与える要因とし ては以下に述べるようなものが考えられる.ただしここ では同一の圧縮試験機を用いて一連の実験を行う場合に ついて考える.

\section{（1）岩石材料固有のばらつき}

岩石材料はその内部にクラックをはじめとする多くの 欠陥や粒子組成の非均一性を含む. そのため一軸圧縮強 度にばらつきが生じると考えられる。

\section{（2）供試体採取方法}

a）採取位置：同一の岩塊から供試体を作製しても位 置により若干のばらつきが存在する、この点については 地質統計学 (geostatistics, たとえば Hudson ${ }^{12)}$ ) の研 究対象としても取り扱われ得る.

b）採取方向：たとえば花崗岩類では岩石内欠樎のも つ異方性のため供試体採取方向すなわちコアボーリング の方向により強度が異なる(たとえば Dale ${ }^{13)}$ ).

（3）供試体形状，寸法

試験結果のばらつきを小さくするためには岩石の最大 結晶寸法の 10 倍以上の供試体直径があること ${ }^{14)}$, また ばらつきとは直接関係がないが，さまざまな粒径を有す る岩石を用いて $\mathrm{Mogi}^{8)}$ が行った研究によると, 正しい 実験結果を得るためには長さ/直径 $(L / D)$ が 2.5 以上で なければならないことが示されており，ISRM の指針 に採用されている(4).

\section{（4）整形精度}

供試体端面の整形は特に重要である. ISRM 指針に 従えば供試体端面は $0.02 \mathrm{~mm}$ の平滑さを, 供試体中心 からの偏りは 0.001 ラジアンあるいは $50 \mathrm{~mm}$ 長に対し て $0.05 \mathrm{~mm}$ を越えてはならないとされている.
（5）圧縮試䀫機の加圧盤と供試体加圧面の接触状況

端面拘束による側圧効果を減じるために加圧盤と供試 体端面の間にテフロンシートなどの減摩剤が用いられる ことがある。これらの減摩剤は供試体端面に局部的な引 張応力集中を生じさせることが Peng and Johnson ${ }^{15)}$ に より示されており，ISRM の指針でも使用は禁止され ている ${ }^{(4)}$ ．減摩材を使用する場合，この種の応力集中の 効果にばらつきが生じるために強度にもばらつきが生じ る.

\section{（6）試倹環境}

温度, 湿度, 含水状態なよ゙のばらつきが考えられる. 特に含水状態のばらつきの影響は大きいと考えられる.

\section{（7）ひずみ速度}

ひずみ速度が大きくなるほど強度は大きくなる。ばら つきを小さくするためにはひずみ速度を一定に保つこと が必要である.

\section{（8）試験機および球座}

試験機は十分な容量をもっている必要があり，また荷 重速度あるいはひずみ速度を一定に制御できることが望 ましい，試験機に付属している球座の良否は安定した実 験結果を得るために特に重要である.この点についても ISRM の指針に述べられているが(14)，その精度および潤 滑性が劣ると効果的に作用しないので, 球座の設計およ び使用状態は重要な項目となる。

\section{(9) 試験技術}

荷重軸と供試体軸の一致, 加圧盤面と供試体端面の一 致など試験技術は特に熟練と慎重さを必要とする.

ここで前に述べた 3 種のばらつきをばらつきの要因の 立場から考えると（1）および（２）のａ）は岩石材料 固有のばらつきを与えるとしてよいであろう. また（2） のb)，（3），(4) は供試体作製上のばらつきを，(5) ～( 9 ) は試験条件のばらつきを与える. また（1）お よび（2）に起因するばらつきは供試体の作製技術や試 験方法によって小さくできる性質のものではない（3 ) の供試体直径亡最大結晶寸法との比が小さくなると, 強 度が大きくなるか小さくなるかは必ずしも明らかではな い.これに比べて（5）の端面拘束および（6）の供試 体の乾燥は一般に強度上昇をもたらし，（）のひずみ 速度の増加もまた強度上昇をもたらす．逆に（4）の整 形精度の低下，（５）の減摩材による供試体端面の局部 的応力集中, （８）の球座の不良, そして（９）の試験 技術の不十分さは強度低下をもたらす。

\section{3. 実験結果のばらつきを小さくするための配 慮}

前章に述べた要因が実験結果に与えるばらつきをでき るだけ小さくするために各要因ごとに以下に述べるよう 


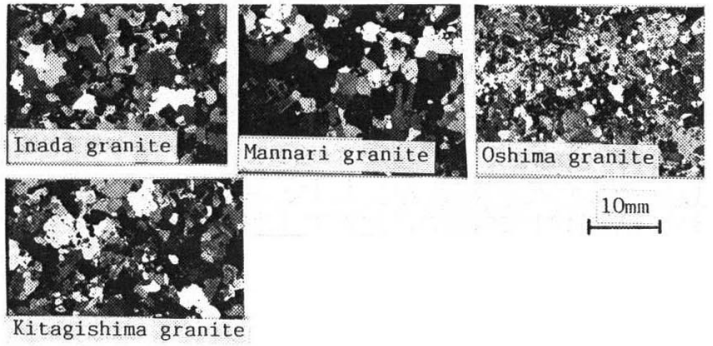

Fig.1 A photograph showing the structure of several granites in Japan. A bar in the figure corresponds to $10 \mathrm{~mm}$ in length.

な配慮を行った。ただし（1）の岩石材料の選択はばら つきを小さくするための配虑というよりも用いた材料の 特性を示すものであるが, 前章との対応上ここに示す.

\section{（1）岩石材料の選択}

実験に用いた岩石は岡山県笠岡市産の北木島花崗岩で ある.この岩石はいわゆる広島花崗岩類に属し, 中粒で 堅硬緻密な岩石である. 岩石力学の研究対象に用いられ ることの多い花崗岩である稲田, 万成, 大島, 北木島各 花崗岩の偏光顕微鏡写真を示すとFig. 1 のとおりであ る. いずれも平均結晶粒径が $3 \mathrm{~mm}$ 以下であり, 特に大 島花崗岩では小さい. 北木島花崗岩の平均結晶粒径は 2 $\mathrm{mm}$ 程度であり，その最大寸法は $4 \mathrm{~mm}$ 程度である.ま たこの写真からは明らかではないが, 北木島花崗岩には 石英および長石粒子中にマイクロクラックが特に多く, 時に長さが $4 \mathrm{~mm}$ を越えるものも認められた. したがっ て北木島花崗岩はFig. 1 に示された岩石の内では比較的 強度も低く, ばらつきも大きいことが推測される.

\section{（2）供試体採取方法}

風化層の影響を避けるため新鮮な面が露出している採 石場にて一辺約 $1 \mathrm{~m}$ のブロックを入手し，その表面を 約 $5 \mathrm{~cm}$ 取り除いた後, $15 \times 50 \times 50 \mathrm{~cm}$ の直方体ブロッ クを計 3 個切り出しコアリングした. 花崗岩には選択的 に割れやすい面が存在することがよく知られており，こ の面が花崗岩の異方性をもたらす ${ }^{13), 15), 16) . こ れ は 内 ~}$ 部に存在する先在クラックの配向性によるものであ $り^{15) \sim 17)}$, 最も割れやすい面を採石場の用語で rift 面, これにほぼ垂直で 2 番目に割れやすい面を grain 面よよ び，これらに垂直な面は hardway 面とよばれる ${ }^{13), 18)}$. 本研究ではさまざまな方向にコアリングすることにより 生じる物性値の変動を避けるためすべて同一方向, すな わち 2 番目に割れやすい面として知られている grain 面 に垂直な方向にコアリングすることにした.

（3）供試体形状と寸法

円柱形供試体の $L / D$ が小さいと見掛け上強度が増加 することが知られている。また $\mathrm{Mogi}^{8)}$ によると, $L / D$
が 2.5 以上となってはじめて本来の強度に収束すること が見出されており，ISRM 指針には $L / D$ を $2.5 \sim 3.0$ とするよう述べられている ${ }^{14)}$. 本研究では長さが異なる ことによる結果の変動を避けるため, $L / D$ が約 2.6 に 等しい円柱形供試体を採用した。また前述した岩石中の 最大結晶粒径 $4 \mathrm{~mm}$ を参考に供試体直径を $44.5 \mathrm{~mm}$, 供 試体長を $115 \mathrm{~mm}$ とした。

\section{(4) 整形方法}

円柱形供試体の端面は十分平滑であること, 軸に垂直 であること，さらに両端面が互いに平行であることが要 求される. 平行度の不足は球座を使用すれば若干改善さ れることが期待できるが, ISRM 指針ではそれらの精 度が厳しく規定されている ${ }^{14)}$. 本研究では供試体の整形 をレンズ加工業者に外注しており，たとえば端面の平行 度は土5/1000 mm 以内におさめられている.

\section{（5）加圧盤との接触状況}

減摩剤は使用しない。 なお直径 $48 \mathrm{~mm}$ のエンドピー スを使用したこと，および（3）で述べたように $L / D$ を 2.6 とすることにより端面拘束の影響を避けることが できる(佐野他 $\left.{ }^{19)}\right)$.

\section{(6) 試験環 境}

含水飽和状態の花崗岩を空気中に放置した場合，最初 の数時間でかなりの包含水が蒸発し, 80 時間後には乾 燥状態に近接することを, 弾性波速度（縦波）の測定に より Nur and Simmons ${ }^{20)}$ は見出した.また岩本 ${ }^{21)} も$ 同 様の実験により,含水飽和に近い状態ではほぼ等方性(縦 波の速度に関して）となる花崗岩が最初の数十分で異方 性が顕著となり，2 週間後には弾性波速度がほぼ室内乾 燥状態の值となることを報告した，本研究では含水状態 を一定にするため供試体整形終了後, 室内にて約 1 年間 保存, 乾燥させた. ISRM 指針 ${ }^{14)}$ に従い求めた含水比の 平均値は $0.0453 \%$ であり，標準偏差は $0.0005 \%$ であ る. なお大気圧下での昇温は数十度のオーダーでも花 崗岩内部のクラックを増加させるという報告があるの で22)，含水比測定に用いた供試体を弾性波速度および圧 縮強度試験に用いることは避けた。試験時間中湿度は制 御していないが, 降雨時の湿度上昇を避けるため試験期 間を雨量の少ない夏に選んだ. 実験室内の温度はほぼ $23 \sim 28^{\circ} \mathrm{C}$ の範囲内にある.

\section{（７）ひずみ速度}

圧縮載荷試験にはMTS 社製サーボ制御材料試験機を 用いて変位速度を制御しており, ひずみ速度は $10^{-6} / \mathrm{s}$ の一定値に保った.

\section{（8）球座}

用いた球座の構造は JIS, ISRM の規格を満足してお り, 球座は供試体端面の平行度の不足を補い得る方向に 回転する.しかしエンドピースをつけたため, 球座の中 
心が供試体表面とは異なること，および球座半径は 60 $\mathrm{mm}$ と大きくその補正は必ずしも敏感ではない点に若干 の問題がある.

\section{（9）試験技術}

載荷試験には細心の注意を払った。特に試験機への供 試体の設置と球座の調整が試験結果に大きな影響を与え ることが予想される．そのため，まず供試体軸方向ひず みがおよそ $100 \times 10^{-6}$ 程度となるまで載荷し，供試体側 面中央の互いに直交する位置にはられた 4 枚のひずみ ゲージの読みがほぼ一致することを確認した。この一致 がみられない場合には除荷し, 球座の調整を行った後, サーボ制御による載荷を開始した。

\section{4. 圧 縮試 験}

前章で述べた配虑をした念入りな圧縮載荷試験を行っ た.ここで行った条件を試験条件 1 とする.

それに対して試験条件のみが異なる圧縮載荷実験を行 うため，2.に示したばらつきの要因（1)（6）に対 する配慮は全く同一とし，（７）～( 9 ）の条件を変化さ せた実験を行った。すなわち試験機としてはアムスラー 型の圧縮試験機を用い, ひずみ速度は試験者が互いに $180^{\circ}$ の位置にある 2 台の差動トランス (LVDT) で計測 される変位をモニターしながら, ひずみ速度 $5 \times 10^{-6} / \mathrm{s}$ となるように手動で制御した．アムスラー型試験機の球 座もまた JIS, ISRM の規格を満足しているが，これも 球座半径が $150 \mathrm{~mm}$ と大きく, さらに潤滑状態がよくな いため半固定座とも考えられる. 試験機への供試体の設 置と球座の調整はひずみゲージによるひずみ值をみるこ となく目視にのみ頼ることとし，供試体端面と載荷圧盤 面とが目視により平行と認められるまで球座の調整を 行った.このようにして行った圧縮載荷試験の条件を試 験条件 2 とする.

ここで試験条件 1 ではできるだけ安定な試験結果を 得, かつ試験過程に種々のデー夕を得るためひずみ速度 を $1 \times 10^{-6} / \mathrm{s}$ としており，供試体の破壊に至るまでに約 1 時間を要した。これに対し試験条件 2 でも当初この載 荷速度で試験することを試みたが，手動制御では 1 時間 にわたる制御は精神的にも肉体的にも容易ではないた め, やむを得ず載荷速度をこの 5 倍とし, 破壊までに要 する時間を 10 分強とした。載荷速度が 5 倍になること によって強度が $5 \%$ 増加することが Sano et al. ${ }^{10)}$ によ り報告されている.

試験条件 1 と試験条件 2 とでデー夕の測定方法には大 きな差はない，すなわち 2 台の LVDT で加圧板間の変 位を計測し，サーボコントローラー（アムスラー型のも のは人間) に入力する.コントローラーは比較信号と比 ベながらジャッキの上げ下げを操作することにより載荷
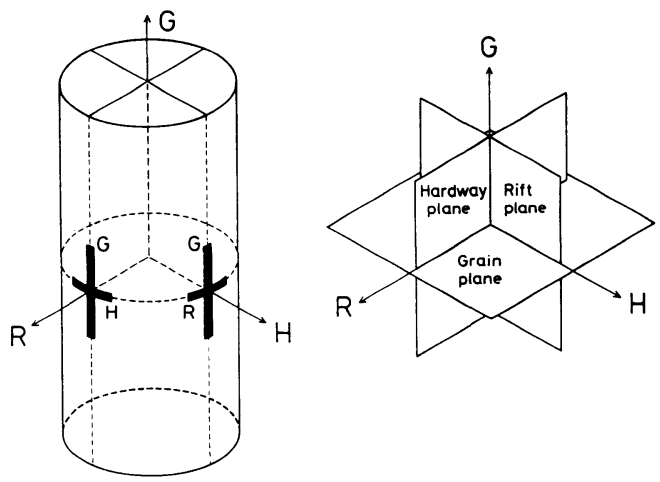

Fig. 2 Specimens of the right circular cylinder were cored normal to the grain plane. An arrangement of electrical resistance gages is also shown. $R, G$ and $H$ indicate the direction normal to the rift, grain and hardway planes, respectively.

する.荷重はMTSを用いたものは $500 \mathrm{kN}$ ロードセル （保証精度 $\pm 0.5 \% \mathrm{FS}$ ) を，アムスラー型を用いたも

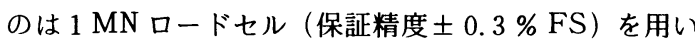
て計測した，供試体の軸方向およびこれに垂直な方向の ひずみは, Fig. 2 に示すように花崗岩の異方性の主軸が 供試体側面之交わる位置, すなわち計 4 か所で計測した. 用いたひずみゲージは長さ $20 \mathrm{~mm}$ のクロス型のもので ある. 荷重, ひずみおよび変形はすべてデータロガーで 計測し, HP-IB バスラインを介してパーソナル・コン ピューターに転送した。

微小破壊のモニタリングなどのためにアコースティッ ク・エミッション (AE) や弾性波速度を計測する場合 には，PZT-7 圧電振動子をシアノアクリレート系の接 着剤を用いて供試体に接着し, 受信子 (あるいは発信子) とした. 弾性波速度の計測はパルス透過法にて行い, パ ルスの周波数を $1 \mathrm{MHz}$ とした。受信波を増幅 $(10 \mathrm{kHz}$

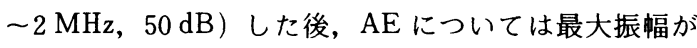
$90 \mathrm{mV}$ を越える現象のみ周波数カウンタで計数し, パー ソナル・コンピューターに転送した．弾性波の波形の記 録に用いたトランジェント・レコーダの分解能は 10 ビットでサンプリング・レイトは $50 \mathrm{~ns}$ である.した がって求められる弾性波速度には $6 \mathrm{~m} / \mathrm{s}$ 程度の誤差が存 在する.

\section{5. 実験結果と考察}

全供試体の材料的なばらつきを検討するため，Fig. 3 に実験に用いた供試体中を伝わる超音波伝播速度（䋛波 速度 $V_{\boldsymbol{p}}$ ）の分布を示す．この計測は著者らの経験によ るとかなり再現性のよいものであるが, 計測結果は平均 值 $3643 \mathrm{~m} / \mathrm{s}$, 標準偏差 $74 \mathrm{~m} / \mathrm{s}$ のほぼ左右対称の分布を 示している. 図より明らかなように，測定精度をはるか 


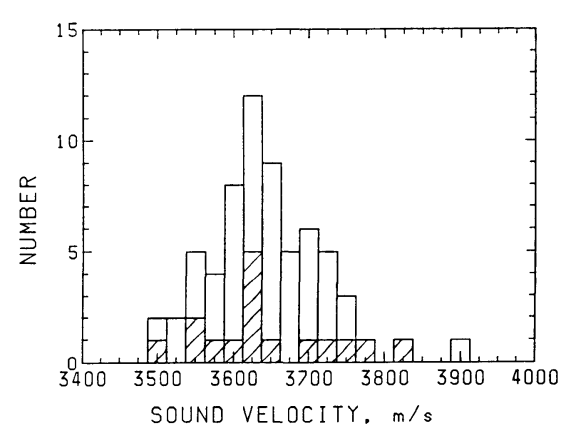

Fig. 3 A spatial variation of the sound velocity in the same direction, showing that the elastic property varies due to its own nature. The mean velocity and the standard deviation are $3643 \mathrm{~m} / \mathrm{s}$ and $74 \mathrm{~m} / \mathrm{s}$, respectively.

に超えてばらついていることが認められる. したがって ここで用いた花崗岩供試体には材料的なばらつきが認め られる.ここで図中斜線をほどこしたものは試験条件 1 の載荷試験用に, 全供試体中から無作為に抽出した供試 体の速度分布である。

Fig. 4 に試験条件 1 で得られた計 16 の応力〜ひずみ 曲線図の内から任意抽出した 3 例を示す.ここで載荷軸 方向のひずみは供試体の側面にはられた 4 枚の軸方向ひ ずみゲージのひずみ值の平均值から，横方向ひずみは向 かい合う位置にはられた 2 枚の円周方向のそれぞれの平 均値から算出している.ただし Fig. 2 に示したように供 試体側面のゲージ配置は供試体軸が, grain 面に垂直と なっていることから, rift および hardway 面に垂直とな る位置となっている.

図中それぞれの応力ーひずみ曲線に付した $\mathrm{G}$ および $\mathrm{H}$ (白抜きの記号)，およびR（黒ぬりの記号）はそれぞ れ grain, hardway, rift 面に垂直な方向のひずみを表わ しており，Vは体積ひずみを表わしている，応力〜ひ ずみ曲線の再現性はきわめて良好である，載荷軸方向の 応力〜ひずみ曲線（G）は立ち上がり部分で大きな非線 形性を示し，この面内におけるクラックの閉塞が生じて いることを示している. Fig. 4 によると横ひずみにも異 方性が現われる.すなわち rift および hardway 面に垂 直な方向の横ひずみの值が異なっており, rift 面に垂直 な方向のひずみが hardway 面に垂直なものよりも若干 大きくなっている. この傾向は rift 面方向亡 hardway 面方向がほぼ等しかった 2 例を除き, 試験条件 1 で得ら れたすべての供試体に共通している。このひずみの違い は rift 面および hardway 面に垂直な方向のポアソン比 が異なること，およびダイラタンシーに異方性 ${ }^{23)}$ がある ことを示しており, 先在クラックの選択的配向性によっ て生じるものと考えられる.

いまこの条件下で計測された $\mathrm{AE}$ 頻度の測定結果の

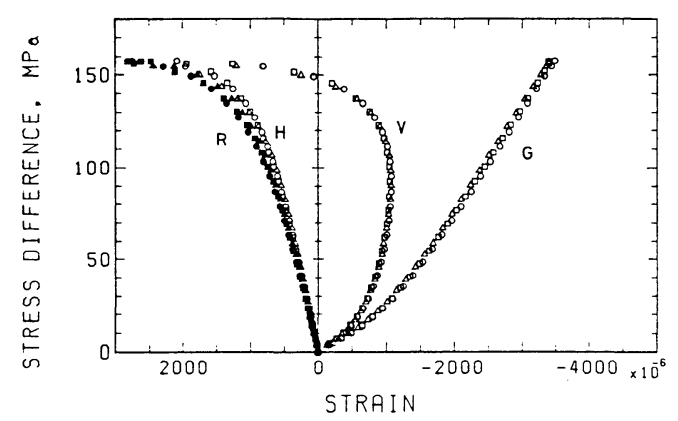

Fig. 4 Three linear strains and volumetric strain observed on three specimens for the carefully arranged experiments (experiments No.1). The reproducibility is excellent.

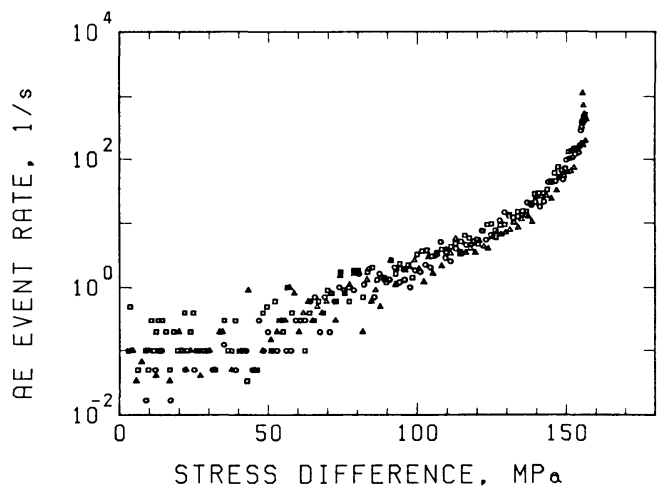

Fig. 5 Event rate of acoustic emissions observed on three specimens for the experiments No. 1. The reproducibility is excellent.

うちから任意抽出した 3 例を示すと Fig. 5 のとおりであ る. $\mathrm{AE}$ 頻度の再現性は良好で各供試体内部で同じよう に微小破壊が生じ, 同じように最終破壊に至っているこ とが認められる. AE は指数関数的に増加し, 最終破壊 に至る過程で急増する．この結果は岩石の圧縮応力下の 破壊がきわめて多数の微小破壊の生成およびその集積の 結果として生じることを示す直接的証拠である.

試験条件 1 で得られた強度の分布をヒストグラムに示 したものがFig. 6 である.Fig. 6 は全 16 個の供試体に ついて示したものであり, 強度の平均值は $154.7 \mathrm{MPa}$, 標準偏差 $2.9 \mathrm{MPa}$ である.すなわち強度の変動係数は $1.88 \%$ となっており，十分に小さいといえる. このこ とから本実験の試験条件 1 において先に述べた，(1)岩石 固有の強度のばらつき,(2)岩石供試体作製上のばらつき， (3)試験条件のばらつきの 3 種類のばらつきはそれぞれ十 分に小さいことが認められる.すなわち大きな欠陷のな い岩石の一軸圧縮強度のばらつきは従来考えられていた ほど大きなものではなく，十分注意深い実験を行えばか なり再現性のよいデー夕が得られると考えられる. 圧縮 


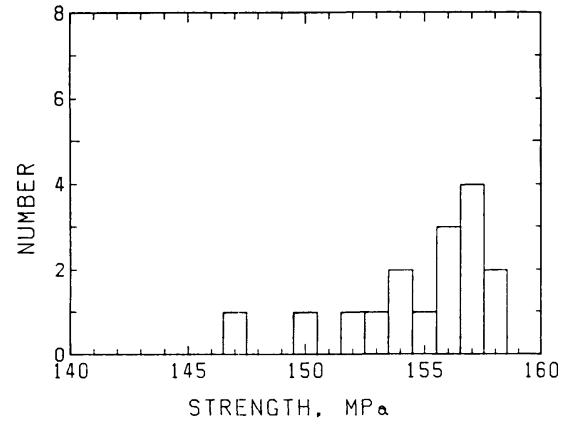

Fig. 6 The strength distribution for the experiments No. 1. The mean strength and the standard deviation are 154. $7 \mathrm{MPa}$ and $2.9 \mathrm{MPa}$, respectively.

応力下の岩石の破壊がきわめて多数の微小破壊の集積に よる6)ことを考慮すれば，最弱リンク説が成立たないこ とは当然とも思える．言い換えれば，比較的小数の微小 破壊により最終破壊に至るような試験条件下では強度の ばらつきは大きくなることが予測される．したがって再 現性のよいデー夕を得るためには微小破壊の大きさと供 試体寸法の間にある条件が成り立つ必要があると思われ る. 最大荷重に接近するまでに花崗岩に生じるクラック には結晶粒内破壊が多いと考えられているので゙)，この 条件は供試体の最小寸法が最大結晶粒径の 10 倍以上で なければならないと定めた ISRM の指針と間接的に結 ばれている.

試験条件 2 において比較的高強度および低強度を示し た供試体の応力〜ひずみ曲線からそれぞれ 3 例を Fig. 7 および Fig. 8 に示す. 図中の記号は Fig. 4 のものと同様 である．比較的高強度を示した供試体の応力〜ひずみ曲 線である Fig.7は試験条件 1 の Fig. 4 と類似したもの之 なっている. しかし比較的低強度を示した Fig. 8 は応力 值が $100 \mathrm{MPa}$ あたりが限界となっているだけでなく，

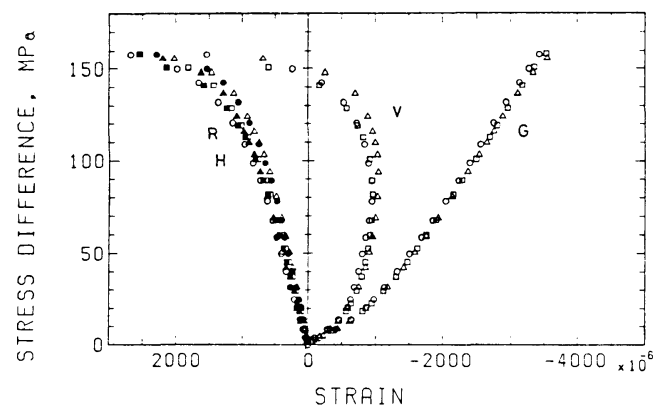

Fig. 7 Three linear strains and volumetric strain observed on three specimens of relatively high strength in experi ments No. 2. The stress-strain relationship is similar to that in No. 1 .

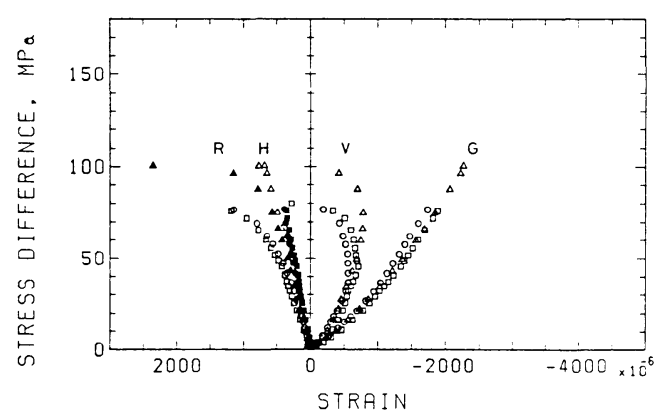

Fig. 8 Three linear strains and volumetric strain observed on three specimens of relatively low strength in the experiments No. 2.

いくつかの点で Fig. 4 と異なる特徴を示している. たと えば最後に計測された体積ひずみが圧縮の状態にあるも のや，試験条件 1 の結果と逆に hardway 面に垂直な方 向のひずみが rift 面に垂直な方向のひずみより大きく なっているものも認められる.

この条件下で計測された $\mathrm{AE}$ 頻度の測定結果のうち から 3 例を示すと Fig. 9 のとおりである.すなわち試験 条件 1 と同様の結果が得られたもの, 比較的強度の低 かったもの，および載荷初期の $\mathrm{AE}$ 発生頻度が強度の 低いものと同様であるが最終的には強度の高かったもの が選ばれている. Fig. 5 と比較するとばらつきが大きく, 同一応カレベルの $\mathrm{AE}$ 発生頻度には最大で 100 倍程度 の差が認められる．また強度の低いものでは荷重の低い 段階から $\mathrm{AE}$ 発生頻度が高くなっていることが認めら れ，より低荷重から微小破壊を発生させる応力状態が生 じていることを示している.

試験条件 2 で得られた強度の分布をヒストグラムに示 したものが Fig. 10 である. Fig.10には試験条件 2 で 行った全 48 個の供試体について示している。この分布

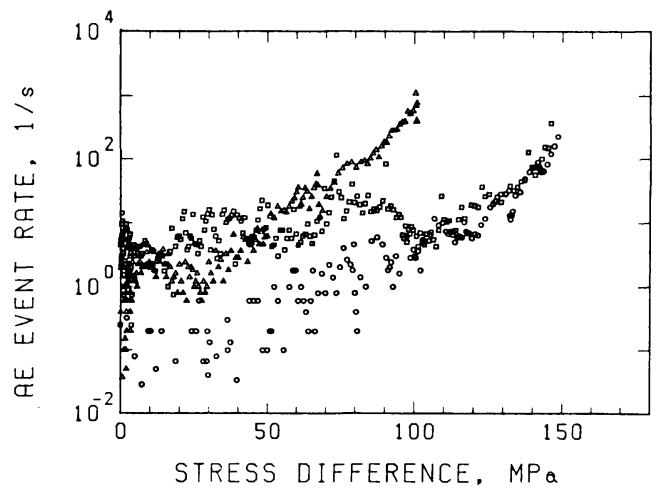

Fig. 9 Event rate of acoustic emissions observed on three specimens for the experiments No.2. The reproducibility is poor. 


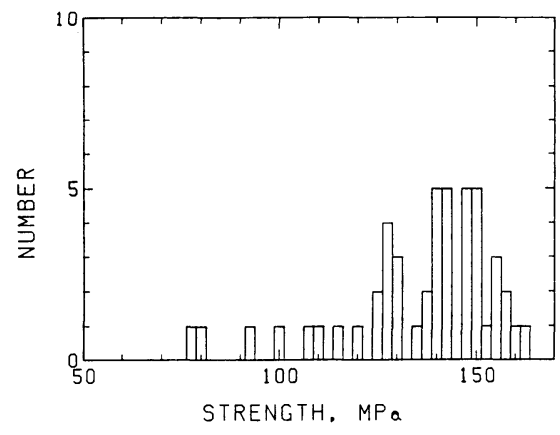

Fig. 10 Strength distribution for the experiments No.2. The mean strength and the standard deviation are 135. $8 \mathrm{MPa}$ and 19.5 $\mathrm{MPa}$, respectively.

形は Fig. 3 に示されている弾性波速度の分布形とは異な り，上限値をもつような非対称分布のような形をしてい る.この試験で得られた強度の平均值は $135.8 \mathrm{MPa}$, 標準偏差は $19.5 \mathrm{MPa}$ であり, 変動係数は $14.4 \%$ と なって試験条件 1 の場合と比べてはるかにばらつきの大 きい結果となっている．しかし両者の分布形を比較する 之強度の分布範囲, 度数は異なるが両者とも非対称分布 となっており，よく似た形となっている．また試験条件 1 の載荷速度は試験条件 2 の速度の $1 / 5$ であることか ら, 試験条件 1 で得られた最大の強度 $157.7 \mathrm{MPa}$ Sano et al. ${ }^{10)}$ に従い $5 \%$ 割り増しすると $165.6 \mathrm{MPa}$ と なり, 試験条件 2 で得られた最大強度 $163.7 \mathrm{MPa}$ より いくらか大きめであるが近い値となる.

試験条件 1 の結果からみられたように, 試験条件 2 に おいても岩石材料固有のばらつきと供試体整形にともな うばらつきはほとんどないはずである。このことから試 験条件 2 で行った実験結果のばらつきはほとんど試験条 件のばらつきによるものと考えられる.しかもここで関 与する試験条件のばらつきは主として2.の（８），（9) に対応しており,これらは強度を低下させる方向に作用 する. すなわち実験の結果得られる強度は真の強度から 試験条件のばらつき分だけ减じた値を与えている．その ため真の強度は得られた強度試験結果の最大值近傍, あ るいはそれより若干高いあたりにあると考えられる。こ のことは載荷速度が $1 / 5$ であるため $5 \%$ 割増しされた 試験条件 1 の結果が武験条件 2 の結果の最大値近傍, あ るいはそれより若干高いあたりに分布することと一致し ている. Fig.10にみられるように試験条件 2 の場合の 強度の分布形は上限値をもつ非対称分布のような形とな る. またこの形は試験条件 1 の場合の分布形 (Fig.6) ともよく似ており, 試験条件 1 の実験においても試験条 件のばらつきが関与している可能性がある.

岩石供試体の強度のばらつきを論じる際によく引用さ

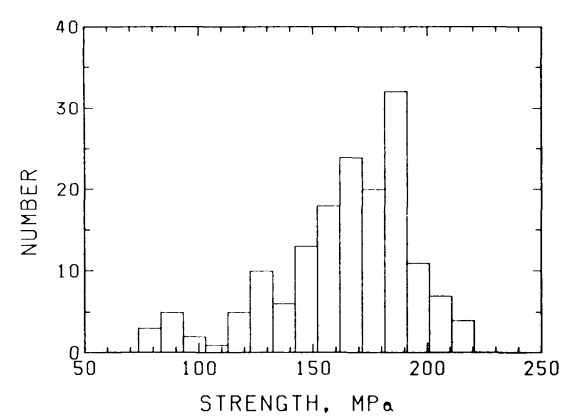

Fig. 11 Strength distribution of Inada granite after Yamaguchi (1967). This resembles to the distribution of experiments No. 2.

れている4),5), 稲田花崗岩を用いて行われた実験結果 ${ }^{1)}$ Fig. 11 に示す.この分布形も Fig. 3 に示されている弾 性波速度の分布形とは異なり，上限值をもつような非対 称分布のような形をしているところが興味深い，またこ の分布形は本研究の試験条件 2 で得られた結果とよく似 ている.したがってこの実験で得られた結果にみられる ばらつきはそこで論議されたような岩石固有の性質では なく, 本研究の試験条件 2 上同様に試験条件によるばら つきの可能性がある. また本来の強度はそこで論議され たような平均值ではなく，はるかに高い可能性がある. ただしそこでは岩石ブロックから互いに垂直な 3 方向に コアリングされた供試体の強度が計測されており, 方向 によるばらつきも関与しているものと考えられる．また 前述の研究が行われた当時から現在までに試験機の機構 のみならず測定系も大きく進歩しており，多点のひずみ 計測がきわめて高速に行えるようになってはじめて武験 条件 1 が可能になったともいえよう.

試験条件のばらつきを生じる大きな原因として載荷の 偏心，あるいは球座の回転などによって生じる曲げモ一 メントの影響がある。そこで供試体側面に $90^{\circ}$ の間隔で 軸方向にはられた 4 本のひずみゲージから最大の曲げ モーメントの作用方向を算定し, 荷重の増加による曲げ モーメント変化の状況を示したものが Fig. 12 である. ただしこの算定には相対する位置で計測されたひずみの 平均值が一致する必要がある. しかし hardway 面と rift 面が供試体側面とそれぞれ交差する位置で計測されたそ れぞれ 2 つの軸方向ひずみの平均值が厳密には一致して いないので, 計算された曲げモーメントの值には若干の 誤差が含まれる．また曲線の最終の値は記録された最大 荷重の 2 測点前（試験条件 1 で 100 秒前, 2 で 20 秒前) で表わしてある. また軸力は平均ひずみより，曲げモー メントは偏差ひずみから求めたものでそれぞれ弾性係数 で割った值が示されている.

図中 $\square$ 印で試験条件 1 の実験結果を，○印で武験条件 


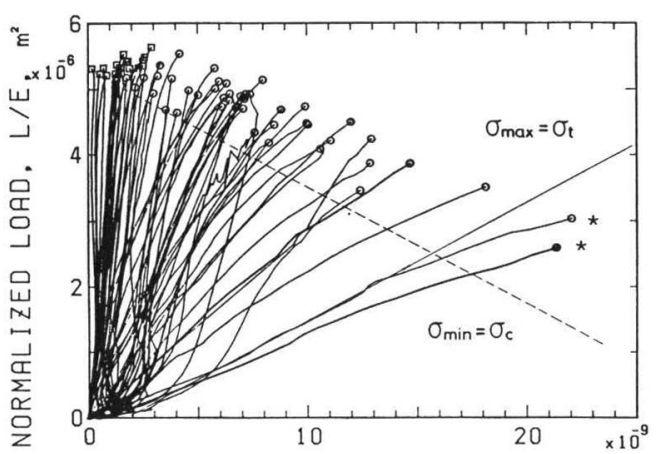

NORMALIZED MOMENT, M/E, $\mathrm{m}^{3}$

Fig. 12 Applied normal force and the bending moment were calculated from the four axial strains observed on each specimen. Squares and circles indicate the experiments No. 1 and No.2, respectively.

2 の実験結果を示している. 曲線が下向きに凸であるこ とは載荷とともに球座が偏心を正す方向に作用すること を意味し，上向きに凸であることはその逆を意味する. このことから試験条件 1 では一般にもともと偏心は小さ く，また球座も良好に作用しているのに比べて，試験条 件 2 では供試体によって球座が偏心を正す方向に作用す る場合とその逆の場合があることを示している.

偏心圧縮柱の理論によると $\sigma_{c}, \sigma_{t}$ をそれぞれ材料の圧 縮, 引張強度として（引張を正とする）

$\sigma_{t}>P / A \pm M / W>\sigma_{c}$

が柱の安全性の吟味の対象とされる.ここで $P, M$ は 荷重と曲げモーメント， $A$ は供試体の断面積， $W$ は断 面係数である.この条件をおよその $\sigma_{c}, \sigma_{t}$ の值を用いて 計算し図中に記入している.これによると断面中に引張 応力が生じて破壊に至ること（図中の実直線）は非常に まれであり供試体の破壊状況から検討して全供試体中に 2 例 (図中*印) 認められるのみである.さらにこの 2 例も Fig. 12 中ではかなり引張応力が大きくなってから 最大応力に至っており, 供試体中に引張破壊が生じても それが直ちに最終破壊に至らないことを示している。ま た縁応力が $\sigma_{c}$ に達して破壊が生じるとすれば実験結果 は図中の破線で与えられることになる，実験結果による と, 強度は必ずしも曲げモーメントに敏感であるとはい えないが，上述の傾向は認められるようである．著者ら は岩石の破壊が必ずしもこのような単純な理論によって 説明できるという立場には立っていないが，圧縮強度に 関する曲げモーメントの影響を定性的に説明することは できるだろう。

一般的には縁応力が $\sigma_{c}$ に近い状態となってその部分 の材料が破壊し (非線形性を示し), 順次破壊が供試体 内部へ進行して最終破壊に至ると考えられる．また曲げ
モーメントが大きいものほど最大, 最小の縁応力の差は 大きい.このことは曲げモーメントが大きいほど供試体 内の破壊の進行過程に差があることを意味する。これを 示すために最大荷重の 2 測点前における体積ひずみをそ の時の荷重に対して示したものがFig. 13である. 図中 の曲線は典型的な応力-体積ひずみ曲線である。これか らダイラタンシー量の少ない供試体ほど強度が低いこ と, すなわち局部的な破壊のみで最終破壊に至った供試 体ほど強度が低いことがわかる。

Fig. 14 に供試体の破壊の状況を示す. 左より順に右 に行くほど低い強度をあたえた供試体となっている，供 試体の破壊の状況は球座の動きやすさなど，最終的なす ベり面の形成状況の影響を受けるため必ずしも載荷条件 に対応するものではない. しかし左端の供試体がほぼ対 称的な壊れ方をしているのに比べて右へ行くほど対称性 がなくなり，右端では曲げによる引張破壊が明瞭に認め られる.

この状況から供試体の破断面の走行を読み取り試験条 件 1 および 2 について図示したものが，Fig. 15 および Fig. 16 である.これらの図では破断面の走行が rift 面 からの角度で表現されており，そのヒストグラムが示さ れている. Fig. 16 に示す試験条件 2 についてのヒスト

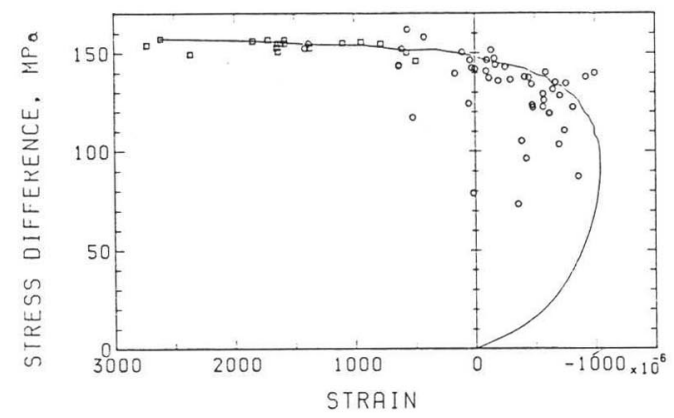

Fig. 13 Volumetric strain near the fracture point and the axial stress. Squares and circles are the same as in figure 12. A typical stress-volumetric strain curve is also shown.

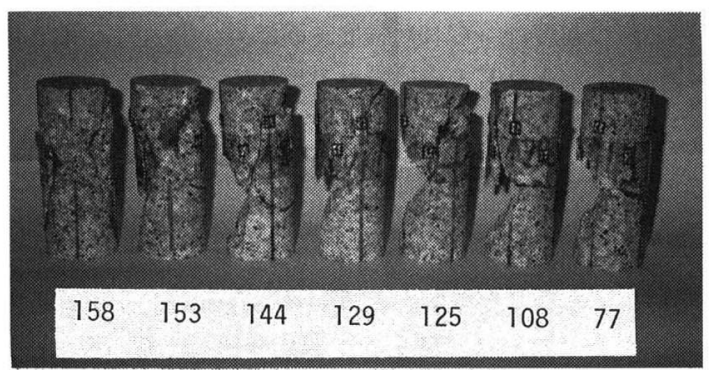

Fig. 14 A photograph showing the fractured specimens. The strength in megapascals for each specimen is also shown. 


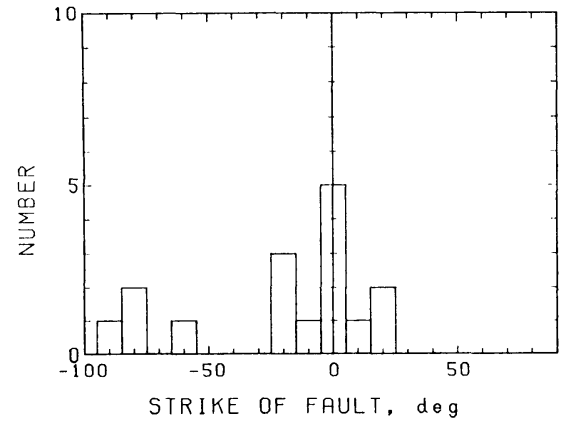

Fig. 15 A histogram of the strike of the fault for specimens No. 1. Almost all the specimens fractured parallel to the rift plane.

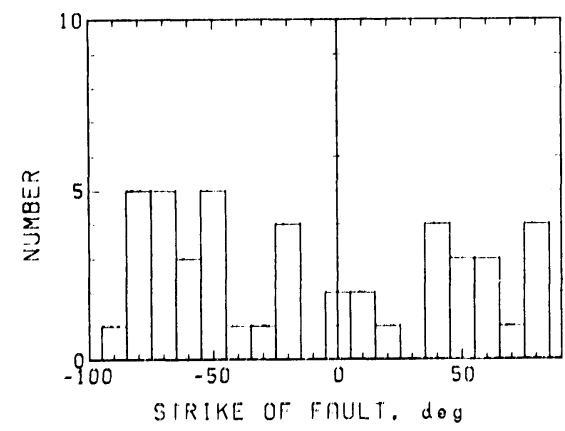

Fig. 16 A histogram of the strike of the fault for specimens No. 2. The strike varied widely.

グラムでは破壊面はほぼ各方向に等しく分布しているよ うであるが Fig. 15 に示す試験条件 1 のみについてみれ ばー25〜 +25 の間に多く分布しており，破壊面方向が 主として先在クラックの選択的配向面 (rift 面) の影響 により決定されることが示されている。このことは Fig. 4 において riff 面に垂直な方向のひずみが hardway 面に垂直な方向のひずみより大きく現われることと対応 している．また精度よく実験すれば実験結果に現われる 花崗岩の異方性の影響も，実験精度がわずかに低下する だけで認められなくなることを示している.

\section{6. 結 論}

物理量の測定には読取り誤差や計器のドリフトなどに よる測定誤差がつきものである．しかし十分慎重な測定 を行うことによりこの種の誤差を小さくすることは可能 である．岩石の一軸圧縮強度は従来この種の誤差よりは るかに大きなばらつきを有するものと考えられてきた。 本研究で示された結果によると, 岩石の一軸圧縮強度の ばらつきは従来考えられていたほど大きなものではな く, 十分注意深い実験を行えばかなり再現性のよいデー タが得られることが認められた。
同一装置を用い, 同一試験方法と同一手順で行われた 試験で得られた結果にもかかわらず，試験条件 2 で得ら れた圧縮強度には大きなばらつきが認められた。しかし これらの供試体側面, 計 4 か所で同時に計測された曲げ モーメントの大きさは強度と明暸な負の相関を示してお り, 試験条件 2 で認められた強度の大きなばらつきは試 験条件, 特に曲げモーメントの載荷によるものと考えら れる. すなわち山口, 西松4)や三木 ${ }^{5)}$ に引用されている 岩石の強度の大きなばらつきは，そこで主張されている ような岩石固有の性質ではなく, 試験条件, 特に曲げモー メント載荷に依存した結果の可能性があることをこの結 果は示している.ただしそこで引用されている実験に用 いられた岩石は稲田花崗岩であり，本研究で用いたもの 之同一ではなく，また強度の異方性が配慮されていない ことも考虑する必要があると思われる.

ひずみや $\mathrm{AE}$ などのパラメーターや破壊面の形成方 向など，丁寧な実験では十分再現性のよいデータが得ら れるが，実験精度がわずかでも低下すると岩石本来の性 質が見失われてしまうことが見出された。

近年，原油や天然ガスの地下備蓄あるいは放射線廃棄 物の地下保管計画などに伴い, 正確な岩石の物性を知る 必要のある機会が増えており, 将来ますますその機会が 増えるものと思われる. 本研究で示された丁寧な実験は 純粋な理学的興味に基づく研究だけではなく，このよう な場合に役立つものと考えられる．しかしすべての場合 にここで述べられたような丁寧な実験を必要とするとは 限らない，そのような場合, 通常の実験から得られた結 果をもとに本来の強度を推定する方法については今後の 課題としたい.

本研究の岩石資料入手にあたり馬越道也氏に多大のお 世話になった。ここに記して謝意を表する。

\section{参 考 文 献}

1）山口梅太郎：花こう岩の強度試験における試験片の数に ついて, 材料, Vol. 16, pp. 52 58, 1967.

2) 西松裕一：岩石の強度之破壊に関する統計学的研究，東 京大学学位論文, 1968.

3）松尾 稔・ 川村国夫・板橋一雄：岩石強度の統計的性質 に関する推定法, 土と基礎, Vol. 31, pp. 11 16, 1983.

4）山口梅太郎・西松裕一: 岩石力学入門第 2 版, pp. 3 5, pp. 95 102, 東京大学出版局, 1977.

5）三木幸蔵：岩盤力学入門, 鹿島出版会, pp. 186 210, 1986.

6) Paterson, M.S. (荻野正二ほか訳) : 実験岩石力学, 古 今書院, 1986.

7) Mogi, K. : Deformation and fracture of rocks under confining pressure, Bull. Earthq. Res. Inst., Tokyo Univ., Vol. 42, pp. 491 514, 1964.

8) Mogi, K. : Some precise measurements of fracture strength of rocks under uniform compressive stress, 
Felsmechanik und Ingenieurgeol., Vol.4, pp. 41 55, 1966.

9) Brace, W. F., Paulding, Jr., B. W. and Scholz, C. H. : Dilatancy in the fracture of crystalline rocks, J. Geophys. Res., Vol. 71, pp. 3939 3953, 1966.

10) Sano, O., Ito, I. and Terada, M. : Influence of strain rate on dilatancy and strength of Oshima granite under uniaxial compression, J. Geophys. Res., Vol.86, pp. 9299 -9311, 1981.

11) Sano, O., Terada, M. and Ehara, S. : A study of the time-dependent microfracturing and strength of Oshima granite, Tectonophysics, Vol.84, pp. 343 362, 1982.

12) Hudson, J. A. : Geostatistics applied to rock mechanics, Proc. 7th West Japan Symp. Rock Engng., pp. 4 20, 1986.

13) Dale, T.N. : The commercial granites of New England, Bull. U.S. Geol. Surv., Vol.738, pp. 1 97, 1923.

14） ISRM 指針：岩の力学連合会, 1982.

15) Peng, S.S. and Johnson, A. M. : Crack growth and faulting in cylindrical specimens of Chelmsford granite, Int. J. Rock Mech. Min. Sci., Vol. 9, pp. 37 86, 1972.

16）工藤洋三・橋本堅一・佐藤 修・中川浩二：花崗岩の力
学的異方性と岩石組織欠陥の分布, 土木学会論文集, 第 370 号, III-6, pp. 189 198, 1986.

17) Simmons, G., Todd, T. and Baldridge, W. S. : Toward a quantative relationship between elastic properties and cracks in low porosity rocks, Amer. J. Sci., Vol. 275, pp. 318 345, 1975.

18) Balk, R. : Structural behavior of igneous rocks, Mem. Geol. Soc. Amer., pp. 27 42, 1937.

19）佐野 修·西村豪人・寺田 孚・伊藤一郎：岩石の変形 挙動および強度に及ぼす荷重速度の影響, 日本鉱業会誌, Vol.96, pp. $141 \sim 147,1980$.

20) Nur, A. and Simmons, G. : The effect of saturation on velocity in low porosity rocks, Earth Planet. Sci. Lett., Vol. 7, pp. 183 193, 1969.

21）岩本 健：ケイ酸塩質岩石のダイラタンシー現象の定量 化に関する研究, 山口大学工学部修士論文, 174 p., 1983.

22) Wong, T. -F. and Brace, W. F. : Thermal expansion of rocks, Tectonophysics, Vol.57, pp.95 117, 1979.

23) Scholz, C. H. and Koczynski, T. A. : Dilatancy anisotropy and the response of rock to large cyclic loads, J. Geophys. Res., Vol. 84, pp. 5525 5534, 1979.

(1987.3.25 - 受付) 